\title{
EFFECT OF FRUIT AND LEAF EXUDATES FOR THE DEVELOPMENT OF ANTHRACNOSE AND RUST PATHOGENS IN UGURESSA
}

\author{
W. M. A. U. K. M. Wijesekara ${ }^{1}$,R. G. A. S. Rajapakse $^{2}$, M. L. M. C. Dissanayake ${ }^{1}$
}

\begin{abstract}
Anthracnose and rust are widely spread diseases in leaves, ripening and ripe fruits of uguressa (Flacourta indica (Burmm.F). Merr) in Sri Lanka. An investigation carried out to determine the effect of fruit and leaf exudates for the development of anthracnose and rust pathogens in fruits and leaves of uguressa. The casual agent of anthracnose (Colletotrichum gloeosporioides) and rust (Uromyces species) diseases were isolated and identified using morphological features of culture media, microscopic observations and Koch's postulation. Exudates obtained from fruits of all maturity stages and leaves were separated into two fractions that are soluble in ether and water to investigate the effect fruit and leaf exudates for the differentiation of spores of both fungi. Conidia of $C$. gloeosporioides germinated and produced appressoria within 22 hours on fruit exudates of all maturity stages of uguressa fruits. The highest stimulation of conidia differentiation of $C$. gloeosporioides was observed in fruit exudates of ripe fruits which are highly susceptible for the anthracnose disease. Chemical substances found in both water soluble and ether soluble fractions enhanced conidia differentiation of $C$. gloeosporioides. Significantly highest lesion development of anthracnose found on ripe fruits compared to mature and immature fruits. Higher conidia differentiation of $C$. gloeosporioides was observed in original exudates of leaves compared to ether and water fractions. There was no effect of leaves and fruit exudates for germination on urediospores of Uromyces species. The study revealed uguressa fruits and leaf exudates have chemical substances to stimulate differentiation of spores of $C$. gloeosporioides and lesion development while there is no any chemical substances that stimulate the differentiation of Uromyces sp.
\end{abstract}

Key words: Anthracnose, Colletotrichum gloeosporioides Exudates, Flacourta indica, Rust, Uromyces species

\section{INTRODUCTION}

Uguressa (Flacourta indica (Burmm.F). Merr) is one of the most popular underutilized fruit crop in Sri Lanka. In many areas of Sri Lanka, during the southwest monsoon a considerable amount of uguressa fruit is lost in pre and postharvest stages due to fungal spoilage. The two most common diseases observed in Sri Lanka, are anthracnose and rust caused by Colletotrichum gloeosporioides

\footnotetext{
${ }^{1}$ Faculty of Agricultural Sciences, Sabaragamuwa University of Sri Lanka, Belihuloya 70140, Sri Lanka

${ }^{2}$ Horticultural Crops Research and Development Institute, Gannoruwa, Peradeniya, Sri lankka
}

and Uromyces species respectively (Rajapakse et al., 2005). Anthracnose disease of uguressa spread throughout the Sri Lanka resulting in premature fruit fall. The most conspicuous symptom of this disease is the production of circular dark, sunken lesions on both ripe and immature fruits. In advanced stages, premature fall of fruit is evident (Jayasinghe and Fernando, 2004). Rust infections usually 
appear as numerous rusty, orange yellow, or even white coloured spots that rupture the epidermis. During the epidemics it affects the leaves resulting severe spots. Most rust infections are strictly superficial local spots, but some may spread internally to some extent (Agrois, 1997). Development of fungal pathogens on the surface of the host is influenced by many factors. Major role played by chemicals, exuded or leached by the host such as fruit peel exudates. (Adikaram et.al., 1983; Swinburne, 1976).

Several species of the genus Colletotrichum, produce appressoria in response to specific chemical signal in host surfaces. Formation of appressoria in C. musae found to be influenced by the chemical signal such as anthranilic acid in plants and cuticular compounds in $C$. gloeosporioides (Harper et.al., 1979). Kolattukudy et. al., 1995 showed that hydroxyl fatty acid monomers in wax of avocado fruit surfaces were involved in the induction of the cutinase gene in conidia of C. gloeosporioides. Stimulatory compounds which are responsible for conidia differentiation into appressoria are present in fruit exudates of brinjal ((Rajapakse, 2000).

The fruit exudates of chilli contain organic and inorganic chemicals that affects for the conidia germination, approssorium formation and the elongation of germ tubes in C. capsici (Rajapakse, 1999). Tony et al., 2001 found leaf chemicals induce wheat stem rust to differentiate the appressoria. French and Wilson (1981) observed compounds related to nicotine in plant leaf having stimulatory effect on germination of urediospores of Uromyces species. The fruits and leaves exudates consist of stimuli which intensifies the establishment of fungi on their surfaces.

Therefore study was undertaken to investigate the effect of fruit and leaf exudates for the development of anthracnose and rust pathogens in fruits and leaves of uguressa.

\section{MATERIALS AND METHODS}

\section{Pathogen isolation and identification}

Anthracnose and rust affected fruits were collected from different localities around the country. Pathogen was isolated from anthracnose lesions of disease affected fruits and cultured on Potato Dextrose Agar (PDA). Isolates of pathogen were collected from mycelia of single conidia cultures grown on PDA. Morphological characters of culture media and microscopic characteristics including shape colour length and width of spore in pure cultures were studied on PDA, and species was identified using illustrated keys (Sutton, 1992).

Rust pathogen was isolated from lesions of disease affected fruits and leaves and preparing spore suspension in SDW, and identified on the basis of the microscopic observation following the description of Punithalingam, 1968a, Punithalingam, 1968b, Laundon and Rainbow, 1971, Sivanesan, 1970. Pathogenicity of all isolates was tested by wound inoculation with spore suspension i.e. pin prick (Rajapakse, 1999) method and subsequent anthracnose and rust development on fruit surfaces was assessed as lesion diameter of each fruit.

\section{Collection of fruit and leaf exudates of uguressa}

Healthy immature, mature, ripe fruits and mature leaves of uguressa were collected from field grown healthy plants. Fruits and leaves were carefully detached from plants, soaked in $70 \%$ ethanol to reduce microbes on fruit and leaf surfaces, washed in sterile distilled water (SDW) and wiped with cotton wool. Five SDW drops of $10 \mu \mathrm{l}$ were separately placed using a micropipette on surface of each fruit and abaxial surface of each leaf and 
kept for 16 hours under moisture chambers in temperature of $28^{\circ} \mathrm{C}-30^{\circ} \mathrm{C}$. Subsequently, the fruit and leaf exudates were collected separately in to the clean bottles and they were stored in deep freezer for further analysis.

\section{Fractionation of exudates}

Compounds in exudates were separated into ether soluble or insoluble fractions. Five mililiters of each exudate were thoroughly shaken with $15 \mathrm{ml}$ of diethyl ether in a separating funnel. The ether fraction was separated from the water fraction by using micropipette. Process was repeated five times and ether washings were bulked and dried over anhydrous $\mathrm{Na}_{2} \mathrm{SO}_{4}$. Then the ether and water soluble fractions were evaporated to dryness using a vacuum evaporator in a water bath at $38^{\circ} \mathrm{C}$ and finally the solutions of ether soluble and insoluble compounds were obtained by adding $5 \mathrm{ml}$ of SDW (Rajapakse et al., 2002)

\section{Bioassay}

Anthracnose and rust pathogens isolated from uguressa fruits were used for all inoculation and bioassay experiments. Conidia of anthracnose pathogen for all experiments were obtained from cultures on PDA incubated for 14 days at room temperature $\left(28^{\circ} \mathrm{C}-30^{\circ} \mathrm{C}\right)$. Conidia were harvested by adding $10 \mathrm{ml} \mathrm{SDW}$ to the culture dishes, which were then gently shaken. The suspension was transferred in to pre sterilized centrifuge tubes, which were then spun at $5000 \mathrm{rpm}$ for $4 \mathrm{~min}$. The supernatant was discarded and the conidia containing pellets were resuspended in fresh SDW. This process was repeated for four times. Rust spore suspensions were prepared by dissolving spores isolated from sporulating lesion of rust affected uguressa fruits in fresh SDW. Density of spores in the final suspension was measured using heamocytometer and adjusted to the $5 \times 10^{5}$ conidia/ $\mathrm{ml}$ with
SDW (Rajapakse, 1998). Ten microliter drops of conidia suspension of anthracnose pathogen were wound inoculated on three sites of fruit surfaces to observe anthracnose lesion development. The experiment involved a completely randomized design with three replicates.

To determined the effect of fruit exudates, its ether soluble and water soluble fractions of fruit exudates on germination and appressoria formation by spores, bioassays were conducted on glass slides. Spore suspension in SDW was mixed with equal volumes of the exudates of ether soluble or water soluble solutions and 10 $\mu 1$ drops were placed on clean glass slides which were then placed in sealed chambers, lined with moist filter paper to prevent evaporation, and incubated for 22 hours at room temperature $\left(28^{0} \mathrm{C}-30^{\circ} \mathrm{C}\right)$. At each time of inspection, slides were removed, briefly dried by placing in oven at $50{ }^{0} \mathrm{C}$ and then a drop of lactophenol trypan blue $(0.03 \%)$ was added. Percent germination and percent germinated spores with appressoria were assessed by microscopic observation.

The experimental design for the observation of germination of conidia in fruit exudates involved two factor factorial experiments in a Completely Randomized Design (CRD), with 3 replicates. Values were based on count of 200 conidia in all replicates. The data were transformed to arc sine and analyzed by ANOVA using a statistical programme (MSTATC).

\section{RESULTS AND DISCUSSION}

The casual agent of anthracnose and rust diseases were confirmed as Colletotrichum gloeosporioides and Uromyces species respectively, using colony morphology on culture media of anthracnose pathogen, spore morphology, presence of setae and from the appressoria on fruit exudates with published data and Koch's postulation. 
C. gloeosporioides isolates tested for their ability to induce lesions in all maturity ability to develop anthracnose lesions on uguressa fruits. The disease was identified by large $0.8-2 \mathrm{~cm}$ diameter, brown, circular depressions and the fungus appeared as brown acervuli on the surface of inoculated fruits.

All isolates tested for their ability to induce lesions in leaves and all maturity stages of fruit using the pin prick method indicated that the tested isolates of Uromyces spp had the ability to develop rust lesions on uguressa fruits and leaves. The disease was identified by large $0.8-1$ $\mathrm{cm}$ diameter, cinnamon brown, circular lesions and the urediospores appeared as spore masses on the surface of inoculated fruits and leaves after 17 days.

Result of germination assay (Figure 1 and 2) showed that there were significant $(\mathrm{p}<0.05)$ differences in conidia germination and appressoria formation of anthracnose pathogen in exudates according to the maturity stages of uguressa fruits after 22 hours incubation. These data indicate that changes in the composition of fruit exudates of all maturity stages over time may stimulate conidia germination and appressoria formation. stages of fruits using the pin prick method indicated that the tested isolates had the

The numbers of conidia that germinated and formed appressoria in fruit exudates were significantly higher in the ripe fruits compared to mature and immature fruits after the 22 hour period of incubation suggesting chemical composition that stimulate the germination of spores and formation of appressoria of the exudates of fruit types increased significantly during ripening.

The number of conidia that germinated and formed appressoria of $C$. gloeosporioides found to be significantly higher in original leaf exudates (Figure 3 ). Conidia differentiation was very low in SDW on glass slides. It was revealed that substances that stimulate conidia germination and appressoria formation are either ether or water soluble. Similar observation was made by Swinburne (1976) with C. musae on banana, which was described, the presence of solutes leaching in to the inoculums drop from the host cell. Rajapakse (1999) showed that $C$. capsici conidia germination and formation of appressoria varied in chilli verities. Padagoda variety of brinjal showed highest stimulation for conidia differentiation in $C$. gloeosporioides (Rajapakse et.al, 2008).

Table 01: Anthracnose lesion size on uguressa fruits of different maturity stages

\begin{tabular}{ll}
\hline Maturity stage & Lesion size*(cm) \\
\hline Ripe & $1.0^{\mathrm{a}}$ \\
Mature & $0.8^{\mathrm{b}}$ \\
Immature & $0.7^{\mathrm{c}}$ \\
\hline
\end{tabular}

*Mean of three replicates

Values followed by same letter with in the column are not significantly different by LSD at $p$ $<0.05$ 


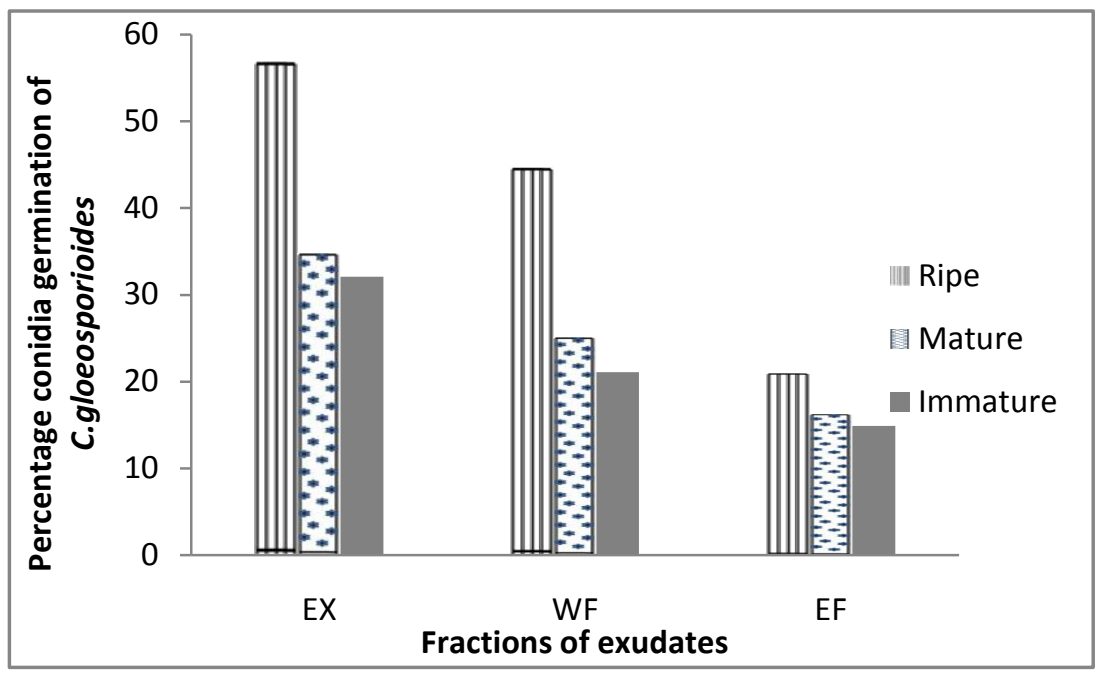

Figure 01: Effect of fruit exudates at different maturity stages of fruits for germination of C. gloeosporioides after $22 \mathrm{~h}$ incubation

$\mathrm{EX}-$ Original exudates, $\quad \mathrm{WF}-$ Water fraction $\quad \mathrm{EF}-$ Ether fraction

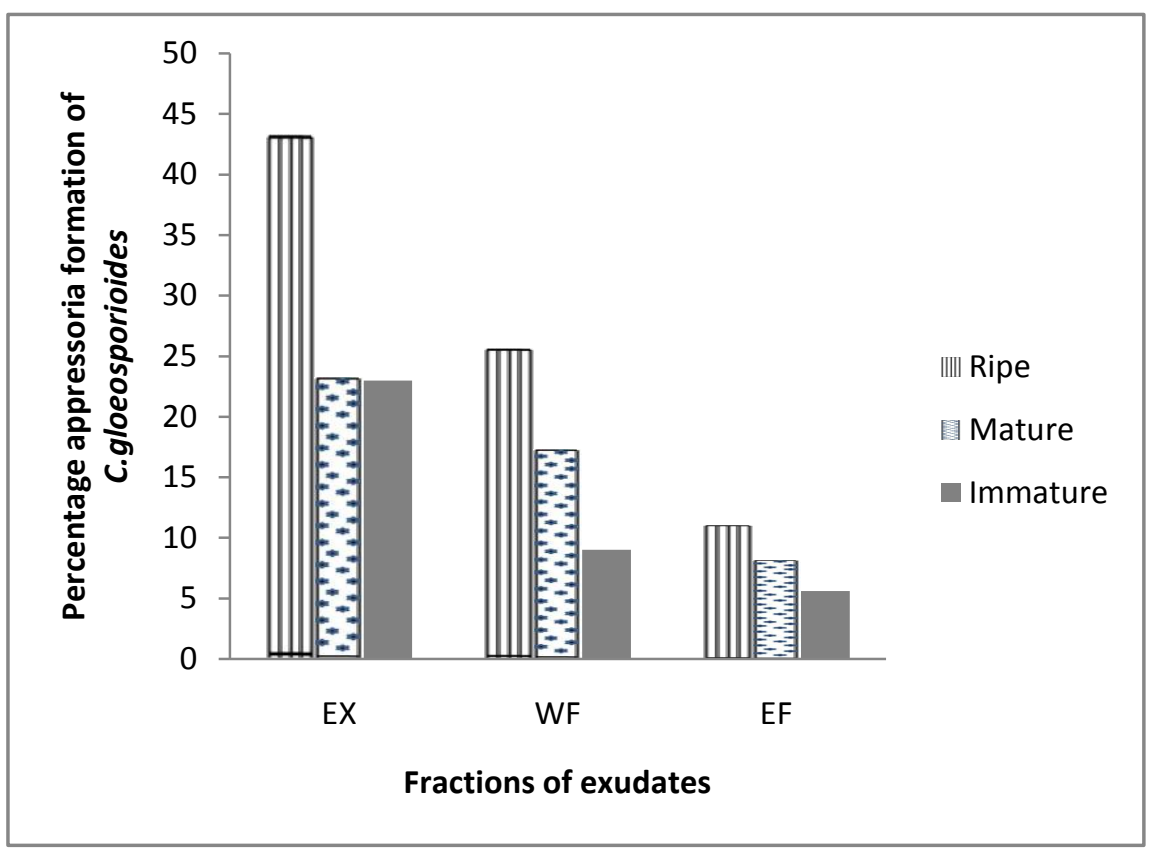

Figure 02: Effect of uguressa fruit exudates at different maturity stages of fruits on the appressoria formation from germinated conidia of $C$. gloeosporioides after $22 \mathrm{~h}$ incubation

EX - Original exudates, $\quad \mathrm{WF}-$ Water fraction $\quad \mathrm{EF}-$ Ether fraction 


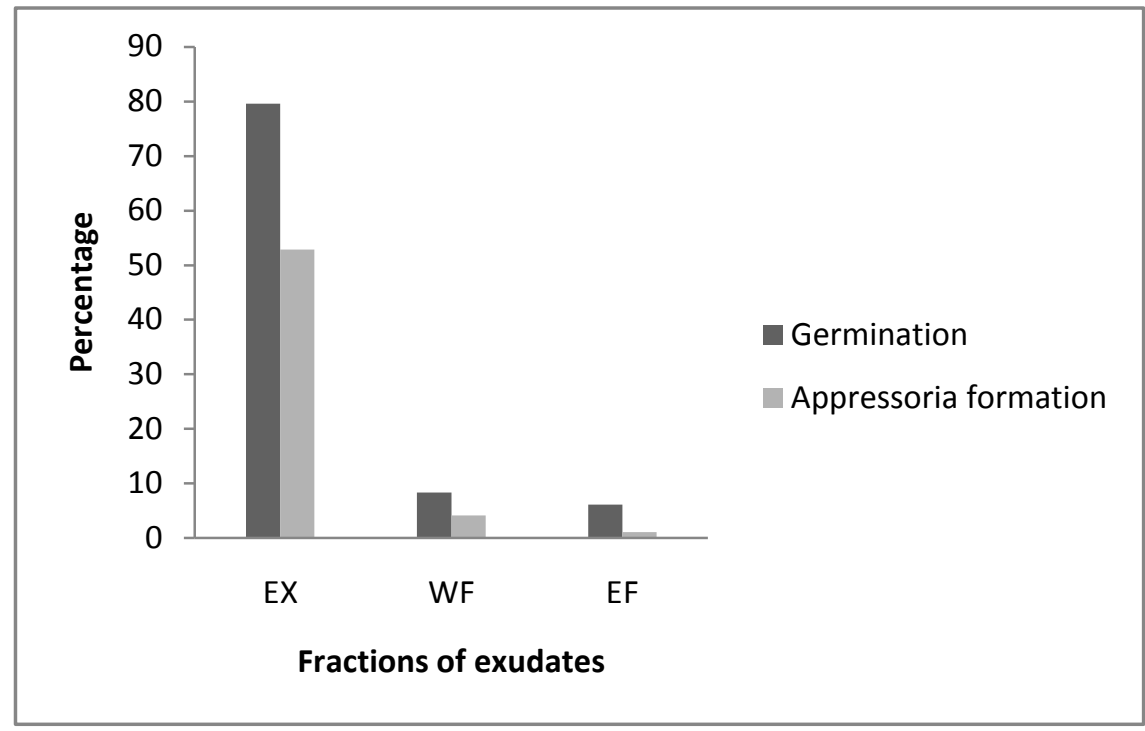

\section{Figure 03: Effect of uguressa leaf exudates for germination and formation of appressoria of $C$. gloeosporioides after $22 \mathrm{~h}$ incubation}

EX - Original exudates, $\quad W F-$ Water fraction $\quad E F-$ Ether fraction

\section{CONCLUSIONS}

There was no either spore germination or appressoria formation observed in fruit and leaf exudates by rust pathogen. That indicates there was no any stimulatory compounds founds in either leaf or fruit exudates for germination of urediospres.

The lesion development was assessed as length of lesion after 4 days of inoculation. Significant differences in anthracnose lesion development were found between the fruits of different maturity stages (Table 1). Highest lesion development was observed on ripe fruits.
Compounds in fruit exudates of all maturity stages of uguressa stimulate the differentiation of conidia of the $C$. gloeosporioides into appressoria. Urediospores of Uromyces species was germinated on fruit and leaf surfaces of uguressa, and there was no effect of leaves and fruit exudates for germination of urediospores of Uromyces species.

Further study on chemical composition of fruit exudates are required to screen the disease resistance or susceptibility of uguressa verities for anthracnose.

\section{REFERENCES}

Adikaram, N. K. B, Brown, A. E \& Swinburne T. R. (1982). Phytoalexin involvement in latent infection of Capsicum annum L. fruit by Glomerella cingulata (stonem). Physiological plant pathology, 21(2): 161 - 170

Agrios, G. N. (1997). Plant pathology, Fourth Edition. United States: Academic Press.

French, R. C. and Wilson, C. L. (1981). The effect of nicotine and related compounds on germination and vacuolation in several species of rust uredospores, Physiological Plant Pathology, 19(2): 201 - 207 
Harper, D. B \& Swinburne, T. R. (1979). 2, 3 - Dihydroxybenzoic acid and related compounds as stimulants of germination of conidia of Colletotrichum muase (Berk \& Curt). Physiological Plant Pathology, 14 (3): 363-370

Jayasinghe, C. K and Fernando, T. H. P. S (2004). Re identification and characterization of pathogens causing uguressa (Flacourtia inermis) fruit anthracnose. Mycopathologia, 157

Kolattukudy, P. E, Rogers M. Linda, Doxin, Li, Hwang, shine. Cheng, Flaishman, and Moshe A. (1995). Surface signaling in pathogenesis, National acedamy of sciences, 92: $4080-4087$

Laundon, G. F. and Rainbow A. F. (1971). Paper No 290 - Uromyces mucunae C.M.I. Descriptions of Pathogenic Fungi and Bacteria. Commonwealth Agricultural Bureaux. Commonwealth Mycological Institute. Surrey, England: Eeasten Press Ltd

Punithalingam, E. (1968a). Paper No.179 - Uromyces decorates in; C.M.I Description of pathogenic fungi and bacteria. Commonwealth agricultural bureau. Commonwealth mycological institute, Surrey, England: eastern press Ltd.

Punithalingam, E. (1968b). Paper No.180 - Uromyces dianthi in; C.M.I Description of pathogenic fungi and bacteria. Commonwealth agricultural bureau. Commonwealth mycological institute, Surrey, England: eastern press Ltd

Rajapakse, R. G. A. S (1998), Some observations of anthracnose disease caused by Colletotrichum species in Sri Lanka. PhD thesis, University of London

Rajapakse, R. G. A. S. (1999). Mode of anthracnose development in chilli (Capsicum annum L) pods. Annals of the Sri Lanka Department of Agriculture, 1: 247 -266

Rajapakse, R. G. A. S and Ranasinhe, J. A. A. D. R. (2002). Development of a varietal screening method for anthracnose disease of chilli (Capsicum annum L.) under field conditions. Annals of the Sri Lanka Department of Agriculture, 10: 129 -136

Rajapakse, R. G. A. S., Ekanayaka, R. and Sumanapala, R.U. (2005). Studies on fruit diseases of uguressa. Annual report on Exploration, Collection, Conservation andCharacterization of Underutilized Fruits. Pp 41

Rajapakse, R. G. A. S, Kalubowila, H. V, Kadanamulla, K. G. and Sakalasooriya, S. M. I. S. K (2007) Chemial factors stimulatory to anthracnose development on brinjal (Solanum melongena L.) fruits. 9: $119-126$

Sutton, B. C. (1992). The Genus Glomerella and its anamorph Colletotrichum. and control. British society of plant pathology. UK: CAB International, Pp 1- 26

Sivanesan, A. (1970). Paper No.270 - Uromyces gerani in; C.M.I. Descriptions of pathogenic fungi and Bacteria. Eds. Surrey, England: Commonwealth Agricultural Bureaux. Commonwealth Mycological Institute

Swinburne, T. R. (1976). Stimulation of germination and appressoria formation by Colletotrichum musae (Berk. and Curt.) Arx.in banana leachate. Phytopathologische zeitschrift, 87: 74 - 324

Tony J. Collins, Bruno M. Moerschbacher, and Nick .D Read. (2001) Synergistic induction of wheat stem rust appressoria by chemical and topographical signals. Vol 58(6): 256 $-266$ 